\title{
TITANIA RECOVERY FROM LOW-GRADE TITANOFERROUS MINERALS
}

\author{
Arao J. Manhique ${ }^{1,2^{*}}$, Walter W. Focke ${ }^{1}$ and Carvalho Madivate ${ }^{2}$
}

1. Institute of Applied Materials, Department of Chemistry, University of Pretoria, Pretoria 002, South Africa

2. Department of Chemistry, Eduardo Mondlane University, Maputo, Mozambique

\begin{abstract}
In this study a novel process for extraction of titanium valuables from its minerals is presented. The process entails roasting of titanium ore with alkaline metal salt, hydrolysing fused cake and dissolution in acid. Optimum conditions were found to be $1 \mathrm{hr}$ fusion at $850{ }^{\circ} \mathrm{C}$, using 2:1 mole ratio, $\mathrm{NaOH}: \mathrm{FeTiO}_{4}$, irrespective of the particle size interval used in this work. It was found that under these conditions $\approx 80 \%$ of titanium was recovered. $\mathrm{Na}_{0.75} \mathrm{Fe}_{0.75} \mathrm{Ti}_{0.25} \mathrm{O}_{2}, \mathrm{NaFeTiO}_{4}$ and $\mathrm{Na}_{2} \mathrm{Fe}_{2} \mathrm{Ti}_{3} \mathrm{O}_{10}$ were the dominant phases at this temperature. The presence of these phases is viewed as beneficial to the economics of the process, it consumes less $\mathrm{NaOH}$. Fusions conducted at $550{ }^{\circ} \mathrm{C}$ or below produced chiefly binary phases, $\mathrm{Na}_{2} \mathrm{TiO}_{3}$ and $\mathrm{NaFeO}_{4}$, reducing process economy. Optimum leaching conditions were $\mathrm{S} / \mathrm{L}=0.26$, leaching at $75{ }^{\circ} \mathrm{C}$, for $15 \mathrm{~min} .85 \%$ of $\mathrm{NaOH}$ were recovered, under these conditions. Leaching obeys shrinking core mechanism model.
\end{abstract}

\section{Introduction}

Titania $\left(\mathrm{TiO}_{2}\right)$ is a white pigment used in paints, paper, plastics, cosmetics and coatings. Its wide application is due to its higher opacity and covering power. There are two commercial methods of $\mathrm{TiO}_{2}$ production, the chloride and the sulphate process. In the chloride process titanium mineral is converted into $\mathrm{TiCl}_{4}$ which is subsequently oxidized at high temperatures. In the sulphate process the ore is converted into sulphate solution and then thermally hydrolysed to hydrous titanium. The later is calcined to produce the pigment (Braun et al, 1992; Nielsen and Chang, 1996; Xue et al, 2009).

According to Pong et al (1995) a commercially viable process has to be environmentally benign, to generate a minimum waste, be able to use all grades of ores and be economically favourable. The above processes are, either environmentally unfriendly, costly, generate high levels of waste or recycle, are unable to process low grade ores, as well as, ores such as anatase, sphene, and perovskite (Bulatovic, 1999; Cole, 2001; Nielsen and Chang, 1996; Van Dyk et al, 2004; Yuan et al, 2005).

Generally low grade titanoferrous ores are submitted to slagging process. The slagging process however faces uncertain future due to its higher energy consumption and green house gases emission. Additionally slagging is unable to treat radioactive ores, since the radionuclides remain in the solid solution during slagging process. With increasingly restringent environmental policies on radionuclides content, further treatment has to be conducted to reduce it. This will result in additional production costs (Nielsen and Chang, 1996; Habashi, 1997; Doan, 2003; Jha et al, 2005; Lahiri et al, 2006; Lahiri and Jha, 2007).

*Corresponding author: Universidade Eduardo Mondlane, Faculdade de Ciências, Departamento de Química. Avenida Julius Nyerere, $n^{\circ}$ 257, Campus Principal. Maputo - Mozambique. Telefax: +258 21493377

Email address: araomanhique@uem.mz 
There is a need in converting the existing methods to ecologically and environmentally friendly and as well as cost effective methods. This study presents a novel process of titania recovery from low grade ores. The process entails roasting of titanium ore with alkaline metal salt. The roasted product is hydrolysed with water, acid and subsequently reacted with sulphuric acid. Alternatively the hydrolysed product can be used as feedstock in chloride process.

\section{Experimental}

\subsection{Materials}

Ilmenite sample was supplied by Kumba Iron Ore Limited, South Africa. It was obtained from Hillendale mine. Iron titanate $\left(\mathrm{FeTiO}_{3}\right)$ chemical analytical grade was obtained from Sigma Aldrich. Sodium hydroxide, hydrochloric acid and sulphuric acid were technical grade obtained from CC Imelmann (PTY) LTD.

\subsection{Methods}

Elemental analyses for ilmenite ore were done in an ARL9400+ wavelength-dispersive X-ray fluorescence spectrophotometer. XRD analyses were performed in a Siemens D-501 automated instrument. The working line was $\mathrm{Cu}-\mathrm{K} \alpha$ (1.542Å). Fourier transform infrared spectra (FT-IR) were recorded in a Perkin Elmer Spectrum RX I system using KBr pellets method. A Mettler Toledo STAR ${ }^{\mathrm{e}}$ TGA/SDTA 851e simultaneous TGA-DTA thermal analyser was used. Particle size distribution was determined using a Mastersizer 2000 (Malvern Instruments). Morphology analyses were conducted in a JEOL 840 SEM (scanning electron microscope). Samples were coated five times in gold. Coating was performed in a SEM auto coating unit E2500 Polaron equipment LTD sputter coater.

\section{Experimental Procedure}

\subsection{Decomposition}

Approximately 30.35 grams of ilmenite were used in each fusion experiment. $\mathrm{FeTiO}_{3}: \mathrm{NaOH}$ mole ratio was varied from 0.25 to 6. The temperature was varied from 300 to $950{ }^{\circ} \mathrm{C}$ ( $50{ }^{\circ} \mathrm{C}$ gradient). Fusion time was varied from 0.5 to 3 hours. Homogenised fusion mixtures were transferred into nickel crucible and placed in muffle previously set at desired temperature. After required fusion time the crucible was removed and allowed to cool to ambient temperature and weighed. All fusion products were subjected to XRD analysis.

\subsection{Fusion Products}

Fusion products were leached with water to remove eventual unreacted $\mathrm{NaOH}$ and to hydrolyse the products, allowing recovering of $\mathrm{NaOH}$ reactant. Some impurities were also removed in the process. The mixture is filtered or centrifuged. The liquid fraction was titrated with standardized $\mathrm{HCl}$ solution to determine recoverable $\mathrm{NaOH}$. 
Solids were further hydrolysed with $\mathrm{HCl}$ solution. The hydrolysed solids were washed three times with water. The residue, composed mainly by hydrous titanium and iron oxides, was reacted with concentrated analytical grade $\mathrm{H}_{2} \mathrm{SO}_{4}$. The resultant slurry was filtered. The solution was subjected to ICP-OES analysis for titanium and iron determination. The solid portion was dried and calcined, and treated as unreacted residue.

\section{Results and discussion}

\subsection{Ilmenite Sample Composition}

Chemical analyses of ilmenite raw material are presented in Table 1. XRD analysis indicated that the sample was mainly composed by ilmenite, with zircon and iron oxide as impurities, with traces of rutile and anatase.

Table 1: Composition of ilmenite raw material (major elements)

\begin{tabular}{lcccccccc}
\hline Component & $\mathrm{SiO}_{2}$ & $\mathrm{TiO}_{2}$ & $\mathrm{Al}_{2} \mathrm{O}_{3}$ & $\mathrm{Fe}_{2} \mathrm{O}_{3}$ & $\mathrm{MnO}$ & $\mathrm{MgO}$ & $\mathrm{CaO}$ & $\mathrm{Na}_{2} \mathrm{O}$ \\
Concentration (\%) & 0.48 & 47.3 & 0.51 & 51.6 & 0.97 & 0.70 & 0.07 & 0.42 \\
\hline Component & $\mathrm{K}_{2} \mathrm{O}$ & $\mathrm{P}_{2} \mathrm{O}_{5}$ & $\mathrm{Cr}_{2} \mathrm{O}_{3}$ & $\mathrm{NiO}$ & $\mathrm{V}_{2} \mathrm{O}_{5}$ & $\mathrm{ZrO}_{2}$ & LOI & Total \\
Concentration (\%) & 0.02 & 0.01 & 0.17 & 0.03 & 0.51 & 0.38 & -2.90 & 100 \\
\hline
\end{tabular}

\subsection{Fusion Temperature}

TG curve obtained using iron titanate (Figure 1) shows an intense mass loss beginning just above $350{ }^{\circ} \mathrm{C}$ and ending at 525 ${ }^{\circ} \mathrm{C}$. The observed mass loss is $6.53 \%$, which is approximately $84 \%$ of the total expected. DTG curve presents a peak at approximately $490{ }^{\circ} \mathrm{C}$.

Using ilmenite ore sample the mass loss begins at comparatively lower temperatures, just above $200{ }^{\circ} \mathrm{C}$ to $560{ }^{\circ} \mathrm{C}$. The stretching of the region corresponds to an overlapping of moisture release with water liberation from the reaction. The DTG curve shows a complex mechanism. This suggests two first-order overlapping reactions, occurring at closer temperatures, less than $50^{\circ} \mathrm{C}$ difference (Wilburn, 2000; Papp et al 2003).

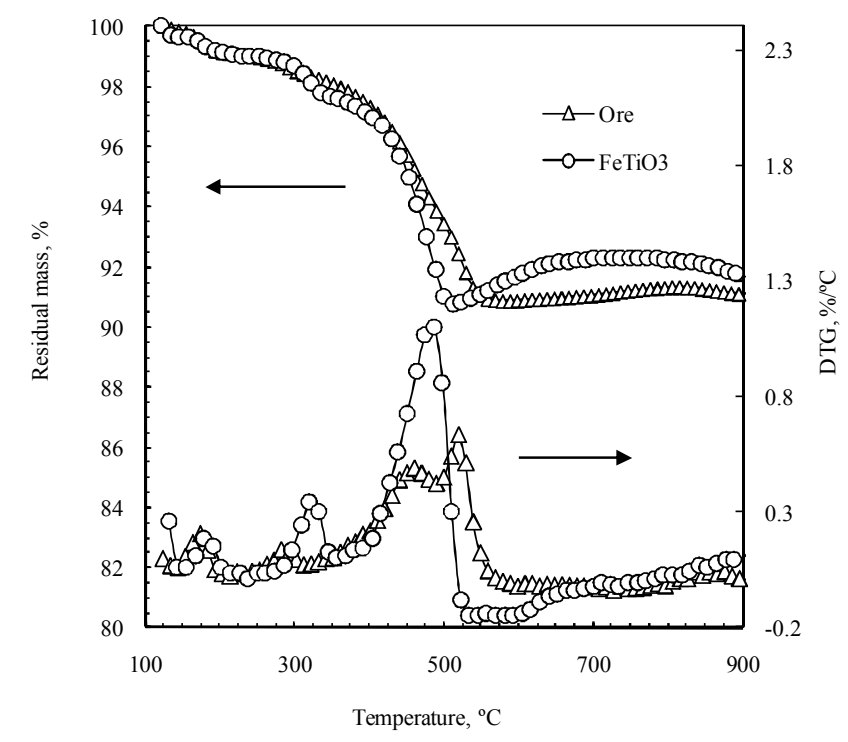


Figure 1: TG curves of ilmenite ore and $\mathrm{FeTiO}_{3}$ reactant (analytical grade) reaction with two mole of $\mathrm{NaOH}\left(10^{\circ} \mathrm{C} / \mathrm{min}\right.$ in oxygen).

\subsection{Alkali Decomposition Reaction}

Although TG results indicate that the reaction initiates just above $250{ }^{\circ} \mathrm{C}$, experiments conducted for 336 hours at this temperature did not produce noticeable changes. Therefore the effect of temperature on the reaction was investigated. $\mathrm{NaFeTiO}_{4}, \mathrm{Na}_{8} \mathrm{Ti}_{5} \mathrm{O}_{14}, \mathrm{Na}_{2} \mathrm{TiO}_{3}, \mathrm{Na}_{2} \mathrm{Fe}_{2} \mathrm{Ti}_{3} \mathrm{O}_{10}$ and $\mathrm{Na}_{0.75} \mathrm{Fe}_{0.75} \mathrm{Ti}_{0.25} \mathrm{O}_{2}$ were identified in our products, by XRD analyses (Figure 2). Bellow $550^{\circ} \mathrm{C}$ ilmenite was still dominant in the products and $\mathrm{Na}_{0.75} \mathrm{Fe}_{0.75} \mathrm{Ti}_{0.25} \mathrm{O}_{2}$ was the main product. $\mathrm{Na}_{8} \mathrm{Ti}_{5} \mathrm{O}_{14}, \mathrm{NaFeTiO}_{4}$ and $\mathrm{Na}_{2} \mathrm{TiO}_{3}$ incidence in the products tend to reduce with temperature while $\mathrm{Na}_{0.75} \mathrm{Fe}_{0.75} \mathrm{Ti}_{0.25} \mathrm{O}_{2}$ increases. The formation of the later however entails the formation of single titanates, mainly $\mathrm{Na}_{2} \mathrm{TiO}_{3}$, since atom ratio Fe:Ti is greater than 1:1, as reported by Foley and Mackinnon (1970). So titanates are concomitant products of $\mathrm{Na}_{0.75} \mathrm{Fe}_{0.75} \mathrm{Ti}_{0.25} \mathrm{O}_{2}$ formation. The following individual reactions can explain the formation of each phase, (1) to (3):

$$
\begin{gathered}
4 \mathrm{FeTiO}_{3}+2 \mathrm{Na}_{2} \mathrm{O}+\mathrm{O}_{2} \rightarrow 4 \mathrm{NaFeTiO}_{4} \\
12 \mathrm{FeTiO}_{3}+6 \mathrm{Na}_{2} \mathrm{O}+3 \mathrm{O}_{2} \rightarrow 4 \mathrm{Na}_{2} \mathrm{Fe}_{2} \mathrm{Ti}_{3} \mathrm{O}_{10}+4 \mathrm{NaFeO}_{2} \\
12 \mathrm{FeTiO}_{3}+14 \mathrm{Na}_{2} \mathrm{O}+3 \mathrm{O}_{2} \rightarrow 16 \mathrm{Na}_{0.75} \mathrm{Fe}_{0.75} \mathrm{Ti}_{0.25} \mathrm{O}_{2}+8 \mathrm{Na}_{2} \mathrm{TiO}_{3}
\end{gathered}
$$

Another possible reaction would be the breakdown of ilmenite structure with formation of single titanates and ferrates (4).

$$
4 \mathrm{FeTiO}_{3}+6 \mathrm{Na}_{2} \mathrm{O}+\mathrm{O}_{2} \rightarrow 4 \mathrm{Na}_{2} \mathrm{TiO}_{3}+4 \mathrm{NaFeO}_{2}
$$

This is coherent with high availability of sodium ions in the melt. Such condition only exists at the beginning of the melting process. $\mathrm{Na}_{8} \mathrm{Ti}_{5} \mathrm{O}_{14}$ results from $\mathrm{Na}_{2} \mathrm{TiO}_{3}$ polymerization according to the following reaction (5):

$$
5 \mathrm{Na}_{2} \mathrm{TiO}_{3} \rightarrow \mathrm{Na}_{8} \mathrm{Ti}_{5} \mathrm{O}_{14}+\mathrm{Na}_{2} \mathrm{O}
$$

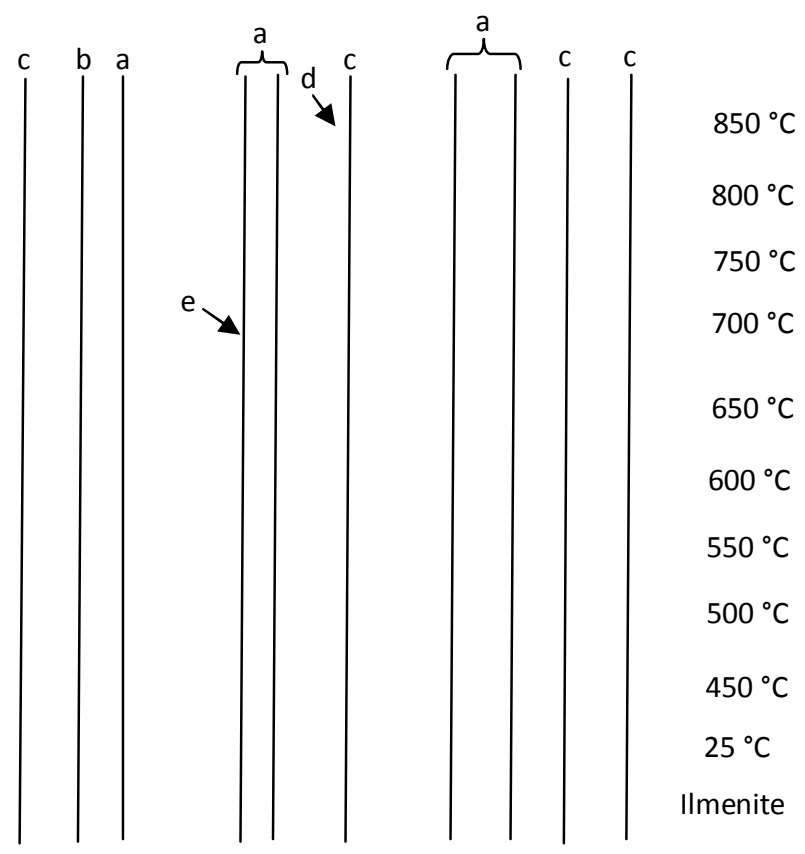




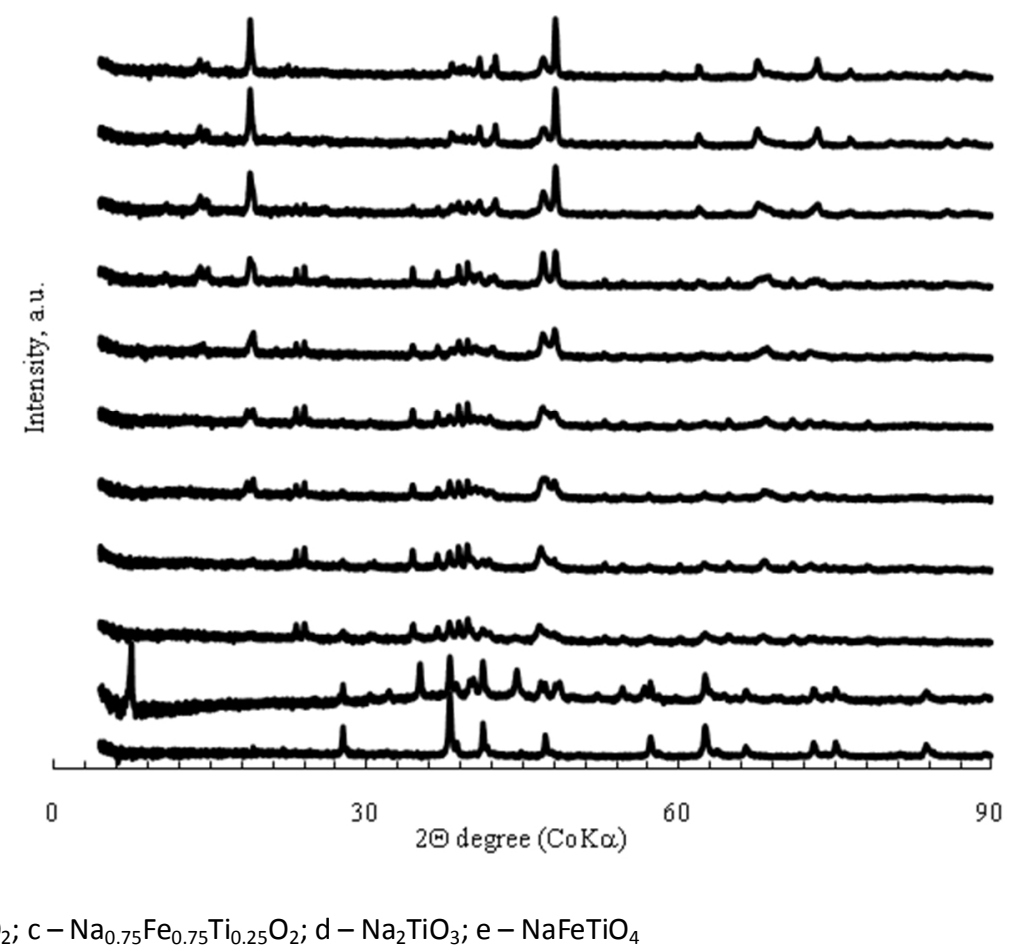

$\mathrm{a}-\mathrm{FeTiO}_{4} ; \mathrm{b}-\mathrm{NaFeO}_{2} ; \mathrm{c}-\mathrm{Na}_{0.75} \mathrm{Fe}_{0.75} \mathrm{Ti}_{0.25} \mathrm{O}_{2} ; \mathrm{d}-\mathrm{Na}_{2} \mathrm{TiO}_{3} ; \mathrm{e}-\mathrm{NaFeTiO}_{4}$

Figure 2: XRD difractograms of the alkali decomposed ilmenite at different temperatures.

$\mathrm{NaFeTiO}_{4}\left(750\right.$ and $\left.800{ }^{\circ} \mathrm{C}\right)$ and $\mathrm{Na}_{2} \mathrm{Fe}_{2} \mathrm{Ti}_{3} \mathrm{O}_{10}\left(800^{\circ} \mathrm{C}\right)$ were observed sporadically. Since those phases coexist in the product spectrum than the reaction will represent a sum of all individual reactions. From our observations and based on published work from other authors the following overall equation was written (Bayer and Hofman, 1965; Reid and Sienko, 1967; Foley and Mackinnon, 1970; Li et al, 1971).

$28 \mathrm{FeTiO}_{3}+22 \mathrm{Na}_{2} \mathrm{O}+7 \mathrm{O}_{2} \rightarrow 16 \mathrm{Na}_{0.75} \mathrm{Fe}_{0.75} \mathrm{Ti}_{0.25} \mathrm{O}_{2}+3 \mathrm{NaFeTiO}_{4}+4 \mathrm{Na}_{2} \mathrm{Fe}_{2} \mathrm{Ti}_{3} \mathrm{O}_{10}+4 \mathrm{Na}_{2} \mathrm{TiO}_{3}$

$$
+2 \mathrm{Na}_{8} \mathrm{Ti}_{5} \mathrm{O}_{14}+10 \mathrm{NaFeO}_{2}
$$

Reaction (6) is consistent with our findings for temperatures above $550{ }^{\circ} \mathrm{C}$. At $550{ }^{\circ} \mathrm{C}$ and bellow $\mathrm{Na}_{2} \mathrm{TiO}_{3}$ was the unique binary titanate in the products. The product spectra composition is sensitive to the temperature as well as to the mol ration ( $\left.\mathrm{NaOH}: \mathrm{FeTiO}_{3}\right)$.

Ilmenite presents lamellar structure (Figure 3a). After reaction ilmenite morphology collapsed producing a disordered cottonseed like structure (Figure $3 \mathrm{~b}$ and $3 \mathrm{c}$ ). At high fusion temperature $\left(850{ }^{\circ} \mathrm{C}\right)$ initial morphology was reacquired. Ternary phases can be regarded as a result of partial substitution of titanium and/or iron by sodium ions in ilmenite lattice (Figure $3 \mathrm{~d}$ ). This was also found by Lasheen (2008) using soda ash. According to this author, sodium iron titanates are favoured at 850 ${ }^{\circ} \mathrm{C}$. 


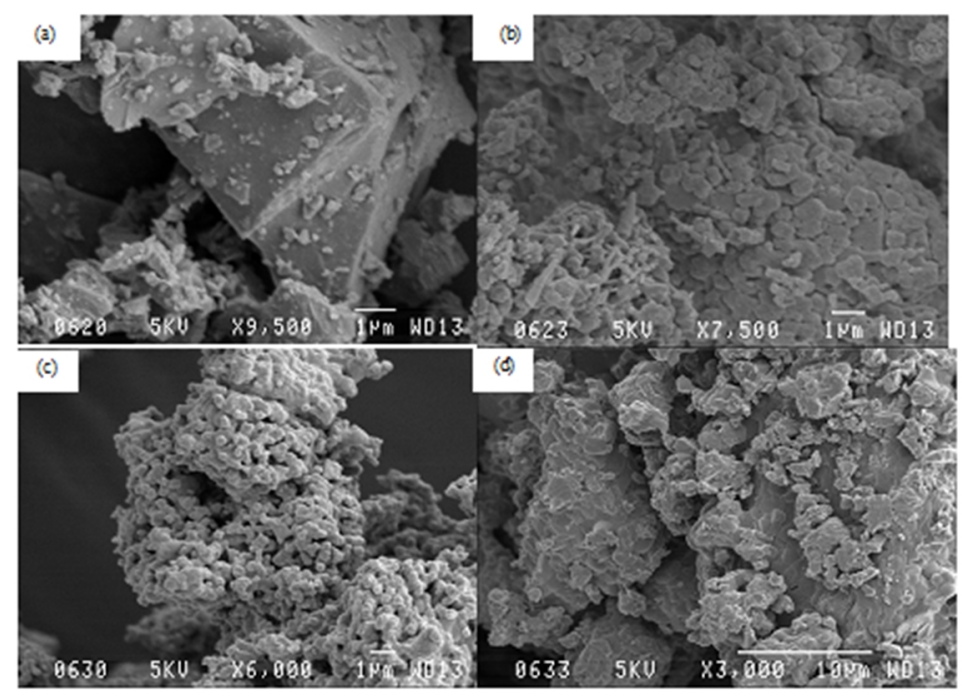

Figure 3: Microstructure evolution induced by ilmenite alkali fusion reaction. (a) ilmenite raw material and $\mathrm{NaOH}: \mathrm{FeTiO}_{3}$ fused at (b) $700{ }^{\circ} \mathrm{C}$ for $1 \mathrm{~h}$; (c) $750{ }^{\circ} \mathrm{C}$ for $1 \mathrm{~h}$; (d) $850^{\circ} \mathrm{C}$ for $1 \mathrm{~h}$.

IR spectra of alkali decomposed ilmenite at various temperatures are presented in Figure 4 (Table 2). In the region above $1600 \mathrm{~cm}^{-1}$ only absorbed water related vibrations were observed. Those were also observed between 2400 and $3800 \mathrm{~cm}^{-1}$, in samples roasted below $600{ }^{\circ} \mathrm{C}$ (Nagarajan and Rajendran, 2009; Ryskin, 1974). The absorption band at $1080 \mathrm{~cm}^{-1}$ observed in all samples is attributed to $\mathrm{Si}-\mathrm{O}$ bonds in $\mathrm{SiO}_{4}$ tetrahedral groups (Farmer, 1974; Vicente-Rodriguez et al, 1996; MéndezVivar et al, 2001; Ratnasamy et al, 2004). Above $700{ }^{\circ} \mathrm{C}$ a weak shoulder is observed at $1130 \mathrm{~cm}^{-1}$ which can be attributed to Ti-O bonds in $\mathrm{TiO}_{4}$ as well as to $\mathrm{O}-\mathrm{O}$ stretching in metal oxide - metal oxide end configuration in solid solutions (Ratnasamy et al, 2004). Ti ion has a very large radius, therefore compounds where Ti exhibit tetrahedral configuration are very rare. It is common when large anions are involved, like in organometalic compounds. Peroxo groups are typical in solid solutions, as in $\mathrm{Na}_{2} \mathrm{O}-\mathrm{Fe}_{2} \mathrm{O}_{3}-\mathrm{TiO}_{2}$ system (Vites and Lynam, 1995; Ratnasamy et al, 2004). The sharp peak at $861 \mathrm{~cm}^{-1}$, changing to a shallow band and disappearing at $800{ }^{\circ} \mathrm{C}$, corresponds to stretching mode of Ti-O short bonds in $\mathrm{TiO}_{6}$ groups. $\mathrm{SiO}_{3}$ groups exhibit symmetric vibration in the same band (Gabelica-Robert and Tarte, 1981). $\mathrm{TiO}_{6}$ group, present in samples roasted between 450 and $700{ }^{\circ} \mathrm{C}$, also absorb around $500 \mathrm{~cm}^{-1}$. $\mathrm{FeO}_{4}$ tetrahedra can be confirmed by the presence of a broad band between 650 and $550 \mathrm{~cm}^{-1}$, changing its shape and splitting above $600{ }^{\circ} \mathrm{C}$ (Tarte et al, 1979). No absorption bands between 950 and 970, related to Ti-O-Si, were observed (Ratnasamy and et al, 2004).

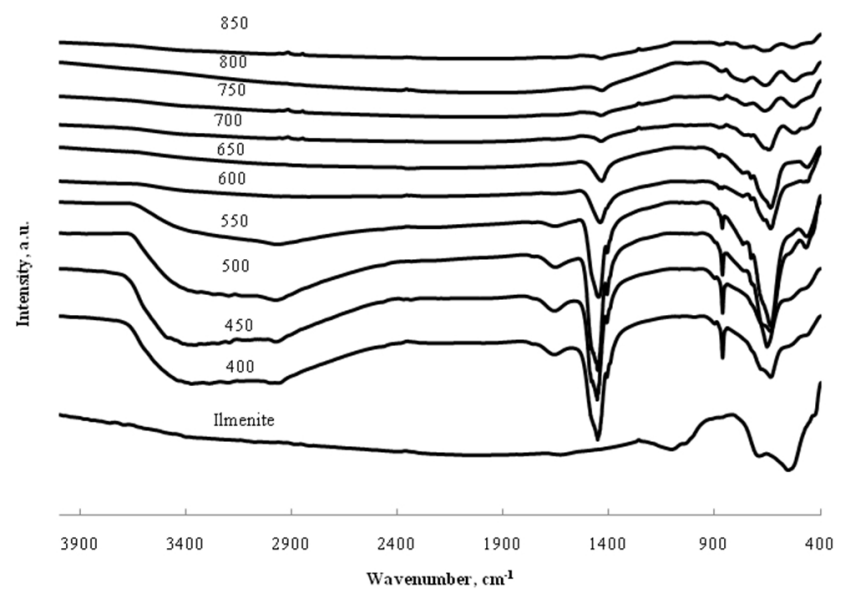

Figure 4: Infrared spectra of alkali decomposed ilmenite at various temperatures. 
Table 2: Assignments of FTIR bands in ilmenite and fused products.

\begin{tabular}{|c|c|c|c|}
\hline Sample & $\begin{array}{l}\text { Band position } \\
\left(\mathrm{cm}^{-1}\right)\end{array}$ & Assignment & References \\
\hline Bellow $600^{\circ} \mathrm{C}$ & 2400 and 3800 & $\begin{array}{l}\mathrm{O}-\mathrm{H} \text { stretching vibration in } \mathrm{M}-\mathrm{OH} \\
\text { groups }\end{array}$ & $\begin{array}{l}\text { Nagarajan and Rajendran, } 2009 \\
\text { Ryskin. } 1974\end{array}$ \\
\hline All & 1600 & Absorbed water & \\
\hline All & 1080 & $\mathrm{Si}-\mathrm{O}$ stretching in $\mathrm{SiO}_{4}$ tetrahedral groups & $\begin{array}{l}\text { Farmer, 1974; Méndez-Vivar et al, } \\
\text { 2001; Ratnasamy et al, } 2004\end{array}$ \\
\hline $700^{\circ} \mathrm{C}$ & 1130 & $\begin{array}{l}\mathrm{Ti}-\mathrm{O} \text { in } \mathrm{TiO}_{4} \text { groups and } \\
\mathrm{MO}-\mathrm{OM} \text { in terminal groups }\end{array}$ & Ratnasamy et al, 2004 \\
\hline Bellow $800^{\circ} \mathrm{C}$ & 861 & $\begin{array}{l}\mathrm{Ti}-\mathrm{O} \text { stretching in } \mathrm{TiO}_{6} \\
\mathrm{Si}-\mathrm{O} \text { symmetric vibration }\end{array}$ & Gabelica-Robert and Tarte, 1981 \\
\hline All & $550-650^{\circ} \mathrm{C}$ & $\mathrm{FeO}_{4}$ tetrahedral groups & Tarte et al, 1979 \\
\hline $450-700^{\circ} \mathrm{C}$ & 500 & $\mathrm{Ti}-\mathrm{O}$ stretching in $\mathrm{TiO}_{6}$ & Tarte et al, 1979 \\
\hline
\end{tabular}

\section{Optimization of the Fusion Process}

\subsection{Effect of particle size}

The particle size effect was tested using coarse particles and fine powder, $\mathrm{d}_{50} \approx 6$ and $139 \mu \mathrm{m}$ (Figure 5). Fusions were conducted at 550 to $900{ }^{\circ} \mathrm{C}\left(50{ }^{\circ} \mathrm{C}\right.$ increments), for one hour fusion time, 2:1 mole ratio $\left(\mathrm{NaOH}: \mathrm{FeTiO}_{3}\right)$. At lower temperatures the coarser raw material produced relatively high amounts of residue. At high temperatures this difference disappeared. The comparatively higher amount of residue observed at 850 and $900{ }^{\circ} \mathrm{C}$ with finer ilmenite was a result of concurrent sintering of ilmenite, which prevented part of the ilmenite to react.

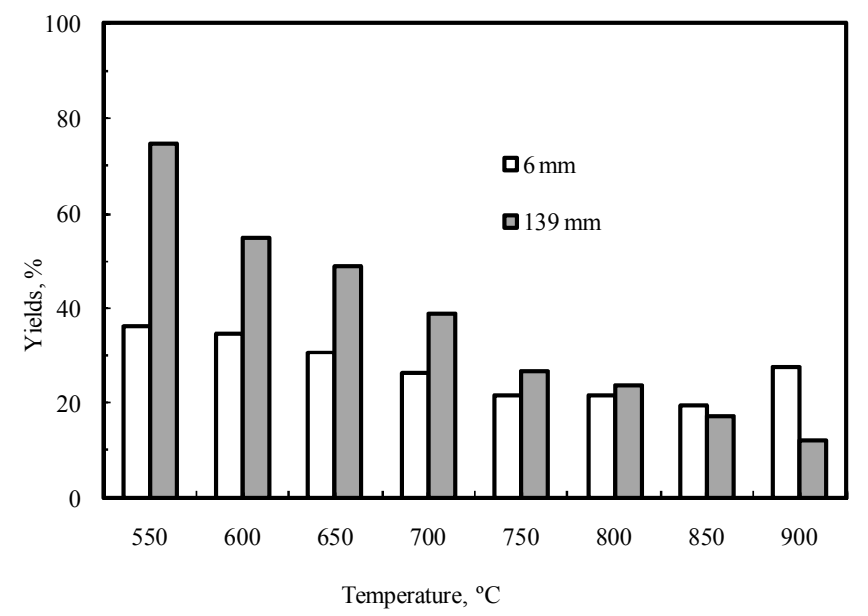

Figure 5: Effect of particle size on the residue produced. 


\subsection{Effect of mol ratio}

Figure 6 indicates a steady increase in the dissolved amount of iron and titanium from 1:4 up to 2:1 (NaOH:FeTiO $)_{3}$. High alkali recoveries are achieved when high quantities of $\mathrm{NaOH}$ per mole of ilmenite are used. Binary phases are predominant which are promptly hydrolysed in water, as shown in Figure 2. Around $96 \%$ are recovered when six mole of $\mathrm{NaOH}$ are used per mole of $\mathrm{FeTiO}_{3}$. A temperature of $850{ }^{\circ} \mathrm{C}$ was used in an attempt to produce ternary phases, sodium iron titanates, especially when fusing below 2:1 mol ratio (Lasheen, 2008). This was also confirmed in this work (Figure 2).

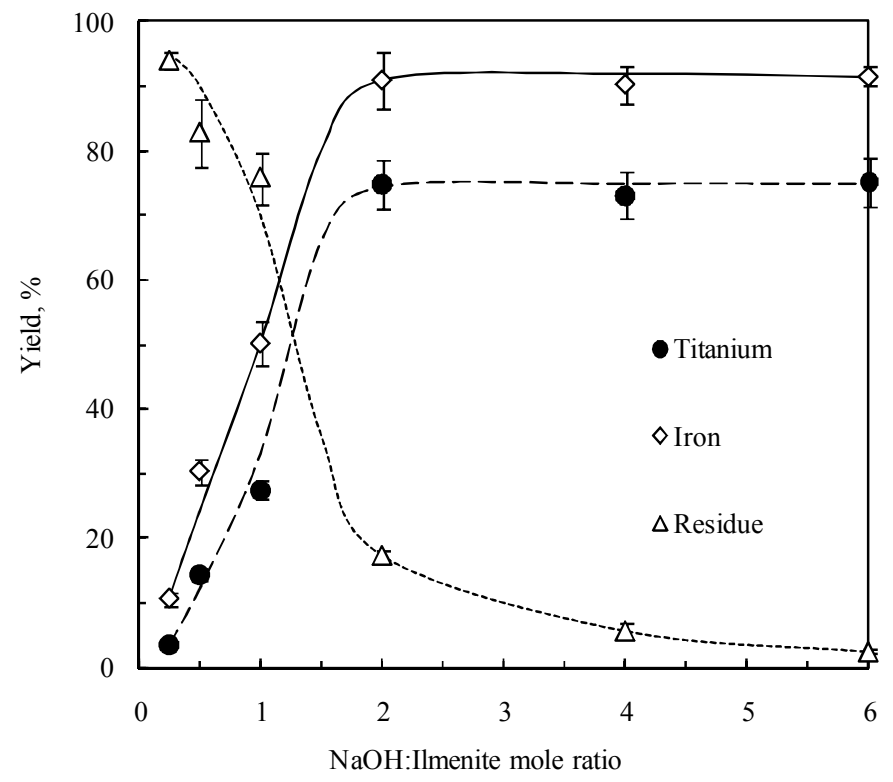

Figure 6: Effect mol ratio on fusions conducted at $850^{\circ} \mathrm{C}$ for one hour.

\subsection{Effect of time}

The effect of time was studied at $750{ }^{\circ} \mathrm{C}$. Fusions were conducted 0.5 to 3 hours, with 0.5 hours increases, using two mole of $\mathrm{NaOH}$ per mole of $\mathrm{FeTiO}_{3}$. This mole ratio was found to be the most efficient in titania release, with $53 \%$ w/w being the theoretical limit. Figure 7 shows a plateau after one-hour fusion, indicating that an extension in fusion period will not increase significantly the reaction yield. 


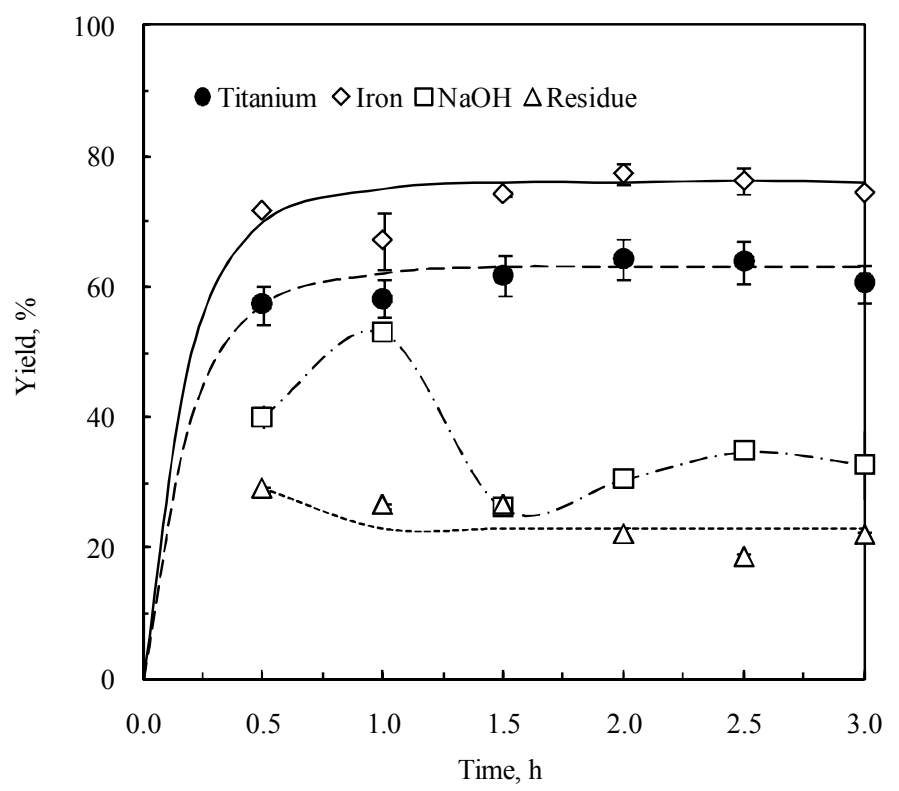

Figure 7: Effect of fusion time on the ilmenite alkali reaction $\left(2: 1 \mathrm{NaOH}: \mathrm{FeTiO}_{3}\right.$ mole ratio, $\left.750{ }^{\circ} \mathrm{C}\right)$.

\subsection{Effect of Temperature}

Temperature effect was examined on the 2:1 mole ratio $\left.(\mathrm{NaOH}: \mathrm{FeTiO})_{3}\right)$, one hour fusion time. Figure 8 show that titania recovery increases as temperature increase, reaching a maximum closer to $850{ }^{\circ} \mathrm{C}, 81 \%$ of the total titanium in the ore were recovered. Higher levels of ternary phases were observed at this temperature from the XRD results, with $\mathrm{Na}_{0.75} \mathrm{Fe}_{0.75} \mathrm{Ti}_{0.25} \mathrm{O}_{2}$ being the main phase, as indicated in Figure 2.

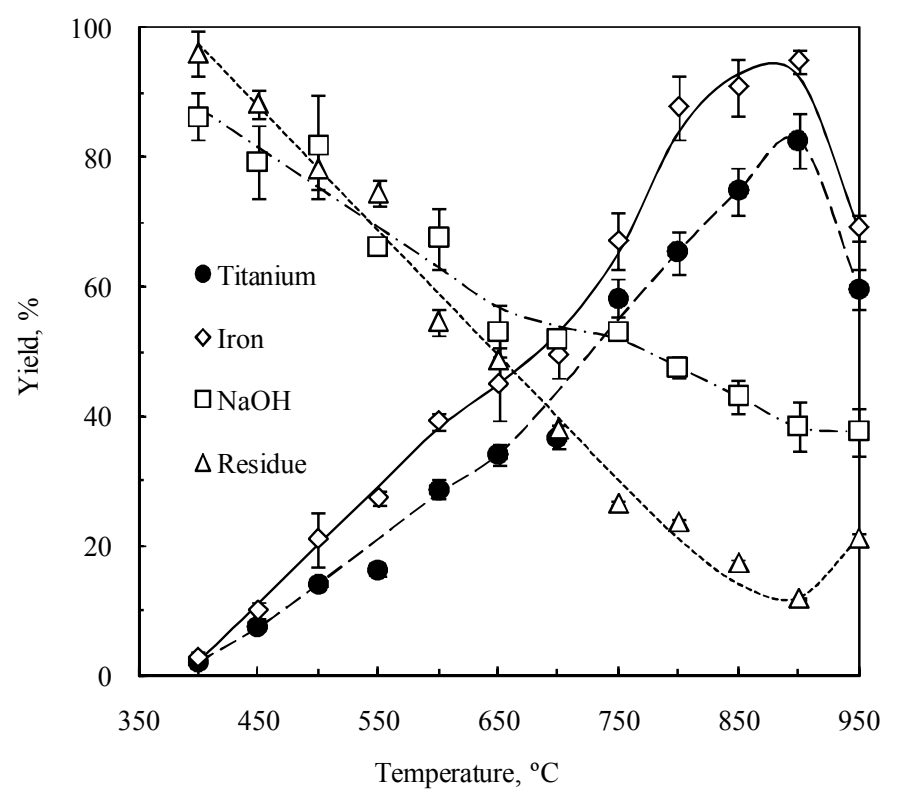

Figure 8: Effect fusion temperature on the titania recovery. Fusions were conducted for $1 \mathrm{~h}$ using 2:1 NaOH:ilmenite mole ratio. 


\section{Leaching}

\subsection{Effect of Solid/Liquid Ratio}

The effect of solid/liquid (S/L) ratio was investigated at room temperature, using alkali fusion decomposed ilmenite product (AFDI) obtained at 2:1 mole ratio $\left(\mathrm{NaOH}: \mathrm{FeTiO}_{3}\right)$, for one hour. Figure 9 indicates that $\mathrm{S} / \mathrm{L}=0.20$ presents optimal extraction conditions. A maximum of $54 \%$ was obtained after one hour of leaching, with $50 \%$ after 30 minutes. In the first 5 minutes no difference in terms of amount of alkali extracted was observed. No significant difference was observed between $\mathrm{S} / \mathrm{L}$ ratio of $2.0-2.6$.

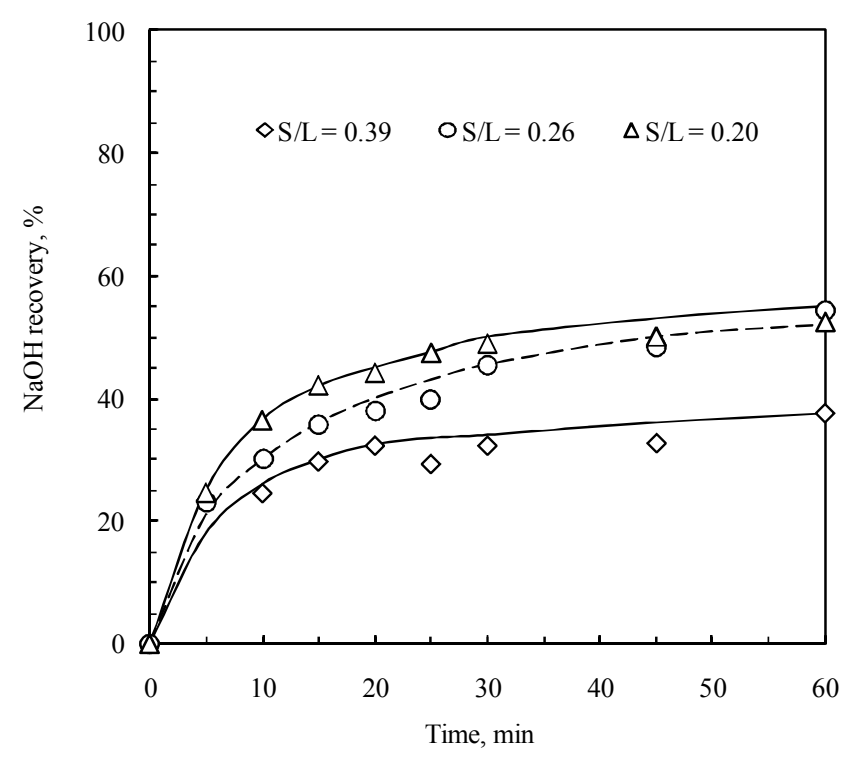

Figure 9: Effect of solid/liquid ratio on the leaching process at room temperature. AFDI samples were prepared by fusing two mole of $\mathrm{NaOH}$ with one mole of $\mathrm{FeTiO}_{3}$ for one hour at $750{ }^{\circ} \mathrm{C}$.

\subsection{Effect of Time and Temperature}

The effect of time and temperature on the leaching process was investigated on 10, 15, 20, 25, 30, 45 and 60 minutes at room temperature, 35, 40, 50 and $75{ }^{\circ} \mathrm{C}$, using AFDI obtained at $750{ }^{\circ} \mathrm{C}, 2: 1$ mole ratio $\left(\mathrm{NaOH}: \mathrm{FeTiO}_{3}\right)$, for one hour. The solid/liquid ratio $(\mathrm{S} / \mathrm{L} \approx 0.26)$ was kept constant. Results are graphically presented in Figure 10. 


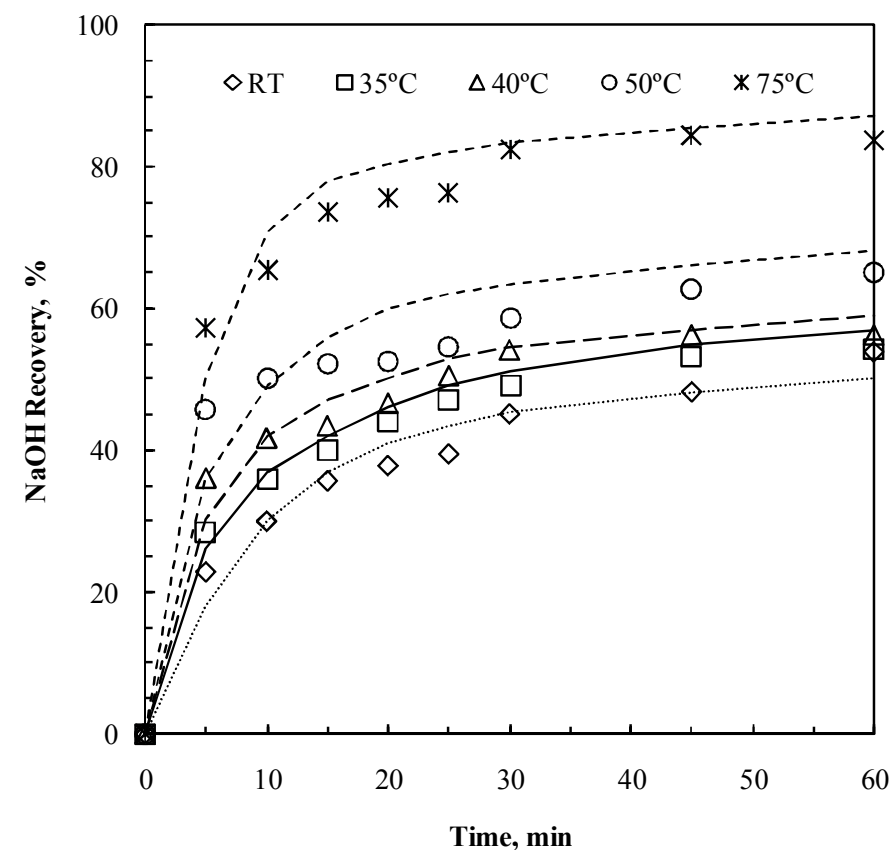

Figure 10: Effect of time and temperature on the leaching process. Samples of AFDI were prepared by fusing two mole of $\mathrm{NaOH}$ with one mole of $\mathrm{FeTiO}_{3}$ for one hour at $750^{\circ} \mathrm{C}$.

In general, alkali recovery increases sharply up to 15 minutes. Above 15 minutes the rate of extraction does not increase. Approximately $75 \%$ of the total $\mathrm{NaOH}$ is extracted after 15 minutes of leaching at $75{ }^{\circ} \mathrm{C}$, while at room temperature only $40 \%$ had been extracted after the same leaching time. The existence of phases that hydrolyse only at high temperatures is the rational explanation for the significant difference.

\subsection{Kinetics of the Leaching Process}

During leaching alkali fusion products are hydrolysed and sodium hydroxide used in the fusion process is recovered. The reactions occurring during hydrolysis can be summarized as follow, according to the net equation presented before:

$$
\begin{gathered}
\mathrm{Na}_{2} \mathrm{TiO}_{3}+2 \mathrm{H}_{2} \mathrm{O} \rightarrow 2 \mathrm{NaOH}+\mathrm{TiO}(\mathrm{OH})_{2} \\
\mathrm{NaFeO}_{2}+\mathrm{H}_{2} \mathrm{O} \rightarrow \mathrm{NaOH}+\mathrm{FeOOH}
\end{gathered}
$$

Ternary phases are stable to aqueous hydrolyses. These phases hydrolyse under acidic conditions as was reported by Foley and MacKinnon (1970). Experimental data was fitted to leaching models in order to determine the rate controlling step and kinetic parameters. According to Demirkiran (2009) these processes are controlled either by diffusion through the film, diffusion through the product layer, or by the chemical reaction at the surface. The mathematical expressions of such models are:

$$
1-(1-\alpha)^{\frac{1}{3}}=\frac{K_{C} M C}{\rho a r_{0}} t=K_{r} t
$$

for surface chemical control and

$$
1-\frac{2}{3} \alpha-(1-\alpha)^{\frac{2}{3}}=\frac{2 M D C}{\rho a r_{0}} t=K_{d} t
$$


for diffusion control, where $\alpha$ is the reacted fraction, $M$ is the molecular mass of the solid, $\mathrm{C}$ the concentration of the leachant in the solution, $\rho$ the density of the solid, $a$ the stoichiometric coefficient of the leaching reaction, $r_{0}$ the initial radius of the solid particle, $D$ the diffusion coefficient in the product layer, $t$ the time, $K_{r}$ and $K_{d}$ are rate constants for the reaction.

In some cases a leaching process can be controlled by a mixed mechanism. In this case the two mathematical expressions are combined, resulting in the following equation

$$
1-(1-\alpha)^{\frac{1}{3}}+B\left[1-\frac{2}{3} \alpha-(1-\alpha)^{\frac{2}{3}}\right]=K t
$$

Where $B=K_{r} / K_{d}$ and $\mathrm{K}$ is the rate constant of the mixed mechanism.

Our experimental data however, did not fit the above proposed models. The most satisfactory was the shrinking core model (Table 3 and Figure 11) proposed by Dickinson and Heal (1999). Dehghan et al (2008) used the same model for experimental data of spharelite leaching with $\mathrm{HCl}-\mathrm{FeCl}_{3}$. The following mathematical equation was used

$$
\frac{1}{3} \ln (1-\alpha)+\left[(1-\alpha)^{-\frac{1}{3}}-1\right]=K t
$$

\begin{tabular}{|c|c|c|c|c|c|}
\hline & \multicolumn{5}{|c|}{ Leaching temperature } \\
\hline & $25 \div C$ & $35 \div \mathrm{C}$ & $40 \div \mathrm{C}$ & 50 -C & $75 \circ \mathrm{C}$ \\
\hline$K\left(\min ^{-1}\right)$ & $3 \times 10^{-4}$ & $6 \times 10^{-4}$ & $10 \times 10^{-4}$ & $7 \times 10^{-4}$ & $24 \times 10^{-4}$ \\
\hline$r^{2}$ & 0.8929 & 0.9151 & 0.8021 & 0.8559 & 0.8813 \\
\hline
\end{tabular}

Table 3: Kinetic parameters of the leaching process.

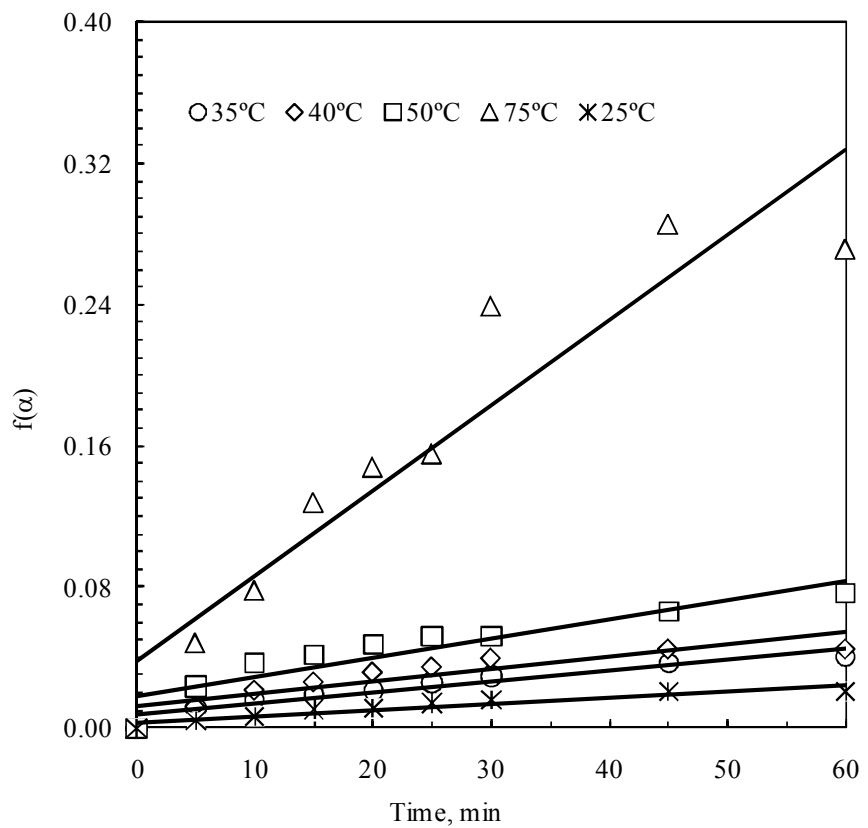

Figure 11: Plot of diffusion controlled mechanism equation. 
The apparent rate constants determined were plotted against temperature, in Figure 12, in order to determine the apparent activation energy $\left(E_{a}\right)$, according to Arrhenius equation. After that the kinetic equation was written as

$$
\frac{1}{3} \ln (1-\alpha)+\left[(1-\alpha)^{-\frac{1}{3}}-1\right]=162.5 t e^{\frac{-3.8826 \times 10^{4}}{T}}
$$

Where $\alpha$ is the conversion degree, $\mathrm{t}$ the time and $T$ the absolute temperature.

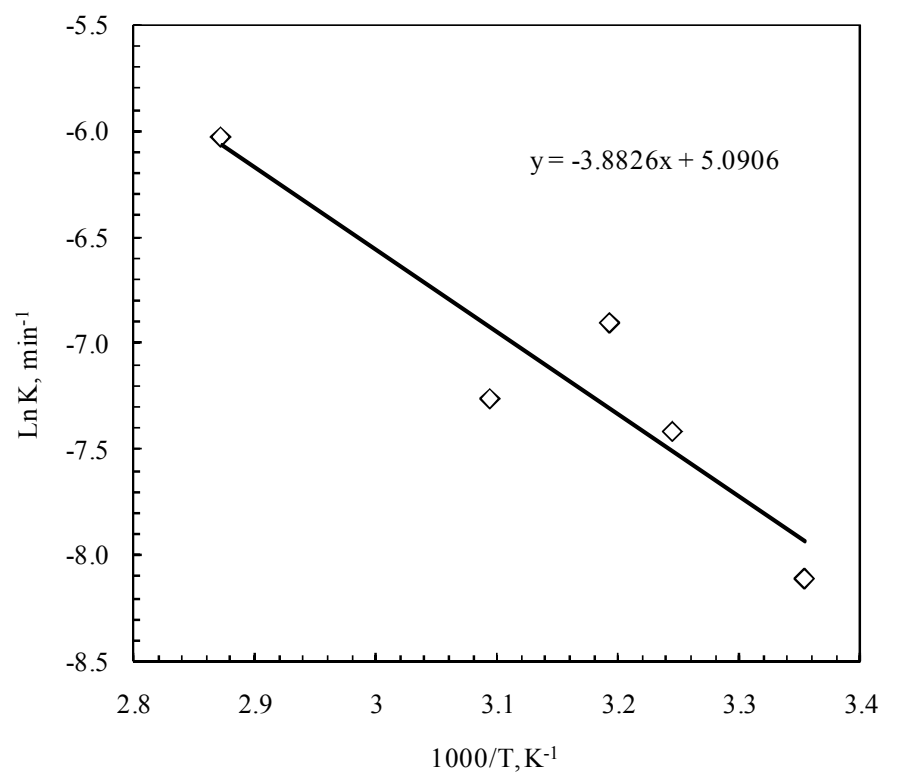

Figure 12: Arrhenius plot of the experimental data.

\section{Conclusions}

A process of utilization of low grade titanoferrous minerals for titania recovery is presented in this work. Titanoferrous minerals were roasted with sodium hydroxide and the cake was leached, hydrolysed and dissolved in mineral acid. The process was found to be temperature, mole ratio and time dependent. Optimal conditions were found to be 2:1 mol ratio $\left(\mathrm{NaOH}: \mathrm{FeTiO}_{3}\right), 1 \mathrm{~h}$ fusion time at $850^{\circ} \mathrm{C}$. Under these conditions $81 \%$ of the total titanium were dissolved. This mole ratio (2:1) releases more titanium per unit mass of $\mathrm{NaOH}$. The reaction extension was found to be independent of the particle size at this temperature, in the interval considered in this work. $\mathrm{Na}_{0.75} \mathrm{Fe}_{0.75} \mathrm{Ti}_{0.25} \mathrm{O}_{2}, \mathrm{NaFeTiO}_{4}$ and $\mathrm{Na}_{2} \mathrm{Fe}_{2} \mathrm{Ti}_{3} \mathrm{O}_{10}$ were the dominant phases in the fusion reaction at $850{ }^{\circ} \mathrm{C}$. These phases are economically beneficial to the process. They consume less $\mathrm{NaOH}$. Working at $550{ }^{\circ} \mathrm{C}$ or below leads to binary phases formation, mainly $\mathrm{Na}_{2} \mathrm{TiO}_{3}$ and $\mathrm{NaFeO}_{2}$, owing to higher alkali consumption. Optimum leaching conditions were $\mathrm{S} / \mathrm{L}=0.26$, leaching at $75^{\circ} \mathrm{C}$, for $15 \mathrm{~min} .85 \%$ of $\mathrm{NaOH}$ were recovered. The leaching process follows the shrinking core model.

\section{Acknowledgements}

Financial support for this research from the University Eduardo Mondlane, Mozambique and the THRIP program of the Department of Trade and Industry and the National Research Foundation of South Africa as well as Xyris Technology CC is gratefully acknowledged. 


\section{References}

Jha, A., Antony, M.P., and Dattatray, T.V., 2007. US Application Patent 20070110647.

Bayer, Von G., Hoffman, W., 1965. Über verbindungen vom $\mathrm{Na}_{\mathrm{x}} \mathrm{TiO}_{2}$ - Typ. Zeitschrift für Kristallographie, 121:9-13.

Braun, J.H., Baidins, A., and Marganski, R.E., 1992. $\mathrm{TiO}_{2}$ Pigment technology: a Review. Progress in Organic Coatings, 20:105-138.

Bulatovic, S., and Wislouzyl, D.M., 1999. Process Development for treatment of complex perovskite, ilmenite and rutile ores. Minerals Engineering, 12[12]:1407-1417.

Cole, A., 2001. All right on the white? $\mathrm{TiO}_{2}$ versus alternative white minerals. Industrial minerals, May 27:31.

Dehghan, R., Noaparast, M., and Kolahdoozan, M., 2009. Leaching and kinetic modelling of low-grade spharelite in HCl$\mathrm{FeCl}_{3}$. Hydrometallurgy, 96[4]:275-282.

Demirkiran, N., 2009. Dissolution kinetics of ulexite in ammonium nitrate solutions. Hydrometallurgy, 95[3-4]:198-202.

Dickinson, C.F., Heal, G.R., 1999. Solid-liquid diffusion controlled rate equations. Thermochimica Acta, 340-341:89-103.

Doan, P., 2003. Sustainable development in the $\mathrm{TiO}_{2}$ industry: Challenges and opportunities. $\mathrm{TiO}_{2}$ Intertech Coference, Miami, Florida.

Farmer, V.C., 1974. The Infrared Spectra Minerals. Mineralogical Society Monograph 4. V.C. Farmer Edition. Mineralogical Society, London.

Gabelica-Robert, M., and Tarte, P., 1981. Vibrational spectrum of fresnoite $\left(\mathrm{Ba}_{2} \mathrm{TiOSi}_{2} \mathrm{O}_{7}\right)$ and isostructural compounds. Physics and Chemistry of Materials, 7:26-30.

Lahiri, A., Kumari, E.J., and Jha, A., 2006. Kinetic studies on the soda-ash roasting of titanoferous ores for the extraction of $\mathrm{TiO}_{2}$. Sohn International Symposium. Advanced Processing of Metals and Materials. Volume 1: Thermo and Physicochemical Principles: Non-Ferrous High-Temperature Processing, 115-123.

Lahiri, A., Jha, A., 2007. Kinetics and reaction mechanism of soda ash roasting of ilmenite ore for the extraction of titanium dioxide. Metallurgical and Materials Transactions B, Process Metallurgy and Materials Processing Science 38[6]:939-948.

Lasheen, T.A., 2008. Soda ash roasting of titania slag product from Rosetta ilmenite. Hydrometallurgy, 93:124-128.

Li, C., Reid, A.F., and Saunders, S., 1971. Nonstoichiometric alkali ferrites and aluminates in the systems $\mathrm{NaFeO}_{2}-\mathrm{TiO}_{2}$, $\mathrm{KFeO}_{2}-\mathrm{TiO}_{2}, \mathrm{KAlO}_{2}-\mathrm{TiO}_{2}, \mathrm{KAlO}_{2}-\mathrm{SiO}_{2}$. Journal of Solid State Chemistry, 3:614-620.

Méndez-Vivar, J., Mendoza-Serna, R., and Valdez-Castro, L., 2001. Control of the polymerazation process of multicomponent (Si, Ti, Zr) sols using chelating agents. Journal of Non-Crystalline Solids, 288:200-209.

Nagarajan, S., and Rajendran, N., 2009. Surface characterisation and electrochemical behaviour of porous titanium dioxide coated 316L stainless steel for orthopaedic applications. Applied Surface Science, 255:3927-3932.

Nielsen, R., and Chang, T.W. 1996. Ullman's Encyclopaedia of Industrial Chemistry. Elvers and Hawkins, $5^{\text {th }}$ edition, Vol. A28, pp 543-567 and 95-122.

Pong, T.K., Besida, J., O'Donnell, T.A., and Wood, D., 1995. A novel fluoride process for producing $\mathrm{TiO}_{2}$ from titaniferous ore. Industrial Engineering and Chemical Research, 34:308-313.

Ratnasamy, P., Srinivas, D., and Knözinger, H., 2004. Active sites and reactive intermediates in titanium silicates molecular sieves. Advances in Catalysis, 48:1-169.

Ryskin, Ya. I, 1974. The Infrared Spectra of Minerals. Mineralogical Society Monograph 4. Farmer, V.C., edition. Adlard and Son Ltd., London. 
Papp, S., Kõrösi, L., Meynen, V., Cool, P., Vansant, E.F., and Dékány, I., 2005. The influence of temperature on the structural behaviour of sodium tri- and hexa-titanates and their protonated forms. Journal of Solid State Chemistry, 178:1614-1619.

Reid, A.F., and Sienko, M.J., 1967. Some Characteristics of Sodium Titanium Bronze and Related Compounds. Inorganic Chemistry, 6[2]:321-324.

Tarte, P., Cahay, R., and Garcia, A., 1979. Infrared spectrum and structural role of titanium in synthetic Ti-garnets. Physics and Chemistry of Materials, 4:55-63.

Van Dyk, J.P., Vegter, N.M., Visser, C.P., de Lange, T., Winter, J.D., Walpole, E.A., and Nell, J., 2004. Beneficiation of Titania Slag by Oxidation and Reduction Treatment. US Patent 6803024.

Vicente-Rodríguez, M.A., Suarez, M., Banãres-Munõz, M.A., Lopez-Gonzalez, J. de D., 1996. Comparative FT-IR Study of Removal of Octahedral of Cations and Structural Modifications During Acid Treatment of Several Silicates. Spectrochimica Acta A, 52:1685-1694.

Vites, J.C., and Lynam, M.M., 1995. Titanium. Coordination Chemistry Reviews, 164:1-281.

Wilburn, F.W., 2000. Kinetics of Overlapping Reactions. Termochimica Acta, 354:99-105.

Xue, T., Wang, L., Qi, T., Chu, J., Qu, J., and Liu, C., 2009. Decomposition Kinetics of Titanium Slag in Sodium Hydroxide System. Hydrometallurgy, 95:22-27.

Yuan, Z., Wang, X., Xu, C., Li, W., and Kwauk, M., 2005. A New Process for Comprehensive Utilization of Complex titania Ore. Minerals Engineering, 19[9]:975-978. 